\title{
A Textbook Evaluation of Speech Acts and Language Functions in Top-Notch Series
}

\author{
Seyyed Mohammad Ali Soozandehfar \\ Shiraz University, Iran \\ Email: soozandehfar@yahoo.com \\ Rahman Sahragard \\ Shiraz University, Iran
}

\begin{abstract}
This study aims at analyzing the conversation sections of Top Notch Fundamental textbooks from the pragmatic dimension of language functions and speech acts. For this purpose, 14 conversations from the entire 14 units of the books were selected randomly and the two pragmatic models of Halliday's (1978) language functions and Searle's (1976) speech acts were applied. The results indicated that the conversations in these newly-arrived textbooks are not pragmatically efficacious and functional. Finally, some implications for teachers, material developers, and textbook designers were proposed.
\end{abstract}

Index Terms - Top Notch Fundamentals, textbook evaluation, pragmatic

\section{INTRODUCTION}

\section{A. The Position of Top Notch Series in Iran}

People learn languages when they have opportunities to understand and work with the language in a context that they comprehend and find interesting. In Iran when new materials are available, people become so attracted towards them that they believe they are the best for learning or teaching. This is exactly in line with the results of Chadran's (2001) study showing that teachers preferred available commercially produced materials in the market over the prescribed textbooks developed by the Ministry, that they do not engage themselves in producing materials of their own, that they consider textbooks out-dated and dull. As a result, nowadays, Top Notch series have become almost the mostfrequently-used series in almost all of the institutes and also most of the tutoring for English language teaching and learning without any preceding evaluation or assessment.

\section{B. Objective of the Study}

The current study concerns with the analysis of the two fundamental levels of Top Notch series conversations from a pragmatic perspective to see how pragmatically rich these textbooks are. As a result, this study performs this pragmatic analysis based on two pragmatic models including Halliday's (1978) Functional Model and Searle's (1976) Speech Act Taxonomy in order to find the different types of language functions and speech acts as well as their frequency, so that the overall pragmatic evaluation of Top Notch Fundamentals can be concluded. Therefore, the following research questions, in particular, will be answered through the present study:

1. What are the types of language functions in the conversation texts?

2. How frequently each language function is used?

3. What are the types of speech acts in the conversation texts?

4. How frequently each speech act is used?

5. Are the conversations of these two Top Notch Fundamentals pragmatically competent and efficient with regard to the existence and the distribution of speech acts and language functions?

\section{LITERATURE REVIEW}

\section{A. Foreign Research on Textbook Evaluation}

Chadran (2001) ran a study about English textbooks used in Malaysian schools. English teachers of over thirty schools in Malaysia participated in informal interviews with the researcher about their feelings, perceptions, values, attitudes and beliefs about the textbooks prescribed to them by the Malaysian Ministry of Education. Results showed that, in general, teachers preferred commercially produced materials available in the market over the prescribed textbooks developed by the Ministry, that they do not engage themselves in producing materials of their own, that they consider textbooks out-dated and dull, and that textbooks were not suitably graded in terms of difficulty.

Morgan (2003) evaluated IELTS preparation materials and showed that there is a need for more materials that are beyond test-taking practice and aim at developing the language competencies that the candidates need for their work or study destinations. In the books, strong motivation of IELTS candidates was seen as taken for granted and therefore, 
there is not any attempt to make the books emotive as visually attractive books do; and this was found to be the problem with the books.

In the realm of pragmatics another study has been done by Otlowski (2003) on the portrayal of gender and the representation of the various ethnic groups in the Expressway A series. The textbook is analyzed for (1) gender bias the depiction of women in stereotypical roles, and (2) ethnic group portrayal- the visibility and depiction of ethnic groups in the text. The conversations and illustrations in each chapter are examined with regard to the above criteria. The results showed that Expressway A, while better than many earlier EFL texts, still depicts women in roles that no longer accurately represent their role in society. The text also gives a very sanitized view of the ethnic make-up of the societies and, in one case, shows a large degree of cultural insensitivity.

Some comparison studies in the area of textbook evaluation have also been conducted one of the most recent one allocated to Vellenga (2004) who makes a comparison between EFL and ESL textbooks. She believes that textbooks rarely provide enough information for learners to successfully acquire pragmatic competence. The results show that the textbooks include a paucity of meta-linguistic and explicit meta-pragmatic information, and the comparison of EFL and ESL textbooks reveals that although the amount of pragmatic information is small across all texts, a larger percentage of pages of EFL texts are comprised to pragmatic information.

In Turkey, Hamiloglu and Karliova (2009) examined and evaluated five selected English language course books from the viewpoint of vocabulary selection and teaching techniques they employ. As an examination and evaluation method, content-analysis was preferred in this study. As a result of this evaluation, it was seen that all selected course books integrated lexis into their syllabuses, giving emphasis to word knowledge by means of separate headings and additional sub-headings, such as Vocabulary, Word Building, Word Formation, Easily Confused Words, Keyword Transformation, Near-synonyms and Synonyms.

Finally, the most recent study in textbook evaluation has been performed by Khalid Mahmood (2010) which aimed at the exploration of textbook evaluation process through analysis of the approved textbooks by the ministry of Education in Pakistan. Eight textbooks in the subjects of science and mathematics, developed in the public and private sector, were analyzed. The results showed that there is a need to make the criteria objective with respect to content coverage in relation to curriculum content scope, concept building, cognition level of assessments given in the end of chapter exercises, format and design, and binding for its durability.

Regarding the foreign studies on textbook evaluation, no study can be found on Top Notch series, particularly on Fundamentals, and especially with regard to the pragmatic dimension applying Halliday's (1978) and Searle's (1976) models.

\section{B. Iranian Research on Textbook Evaluation}

A valuable study has been conducted by Tavakoli (1995) and it concerns with the language functions in the dialogues inserted in the English textbooks of Iranian senior high schools. The data are analyzed based on Searle's (1976) model of speech acts as criteria for evaluating the dialogues to see whether the different kinds of speech acts are correctly used. She has revealed that out of five different kinds of language functions, only three of them i.e. representative with high frequency, directive, and expressive were used in the texts. While commissive and declaration have been ignored.

Ansary and Babaie (2002) scrutinized a corpus of 10 EFL/ESL textbook reviews plus 10 EFL/ESL textbook evaluation checklists conveniently sampled while presenting a summary of common-core characteristics of standard EFL/ESL textbooks in their investigation, too. They tried to look for some theory-neutral, universal, and broad consensus-reached characteristics of EFL/ESL textbooks, and draw up some guidelines for the generation as well as systematic evaluation of EFL/ESL textbooks. They concluded that however perfect a textbook is, it is just a simple tool in the hands of teachers and what is more important than a textbook is what we, as teachers, can do with it.

In the realm of task- based and pragmatics Iraji (2007) conducts a research and makes a careful analysis on New Interchange series based on the principles of communicative and task-based approach to investigate to what extent the principles of CLT and TBLT approaches have mean regarded. In this regard, she employs Ellis's model (2003). Iraji (2007) criticizes New Interchange because the series do not follow the principles of communicative and task-based approaches as the author claimed. It has no frequency of meta-pragmatic information.

In the area of pragmatics one study has been conducted by Darali (2007). She made a careful analysis on Spectrum series with the application of six models proposed by Searle (1976), Leech (1983), Matreyek (1990), Holms (1990), Leech (1983) and Thomas (1983), and Halliday (1978). She reported that the series have provided a variety of language functions, but some important language functions that are used in everyday conversation more frequently, e.g. promising, vowing, and threatening, not only were in the form of unintended function, but also they were not as frequent as others.

Razmjoo (2007) used the Hymes' (1972) scheme to investigate the extent to which the Iranian high school and private institute textbooks represent the CLT principles. To this end, the textbooks of the Iranian high schools and private institutes were analyzed descriptively and inferentially. The analysis of the data indicated that while high school textbooks are not conductive to CLT implementation, private institute textbooks represent the CLT principles to a great extent.

Riazi and Aryasholouh (2007) also studied the four high school and pre-university English textbooks focusing on the consciousness-raising aspect of vocabulary exercises. They found that of all exercises in the four books, only one 
percent of them could be categorized as consciousness-raising. They also found that the exercises mainly concentrated on individual words (approximately $26 \%$ ) with no emphasis on fixed expressions, lexical collocations (approximately $15 \%$ ) and grammatical collocations (approximately 2\%). They concluded that students are mainly dealing with meanings of individual words and not with how words are used with other words or in what combinations.

Zare Moayedi (2007) carried out an evaluation on a series of ELT materials namely, Interchange third edition. For this purpose, Littlejohn's (1998) detailed framework was employed in this attempt. Results indicated that the Interchange series are not completely in line with the objectives intended for it. They do not use learners or even the teachers as a source for its content. Supra sentential level as well is ignored for both the expected output and input of the learners. More importantly, these are not the learners who initiate the tasks. Interchange series, on the other hand, focus mainly on pair works and meaning. They also encourage students to use the language and more importantly they more often require them to express themselves than to be a listener.

Gordani (2010) explored different types of learning objectives inherent in Iranian guidance school English textbooks from the viewpoint of Bloom's taxonomy. The primary data in this study were the English textbooks taught in Iranian guidance schools at the present time. The study used Bloom's taxonomy of educational objectives (1956) in analyzing the material found in Iranian guidance school English textbooks. The results showed that all of the items were concentrated in the first three levels of Bloom's taxonomy which are referred to as the lower levels of cognitive skills. In addition, a significant difference was found between the textbooks in their inclusion of different levels of cognitive skills. Riazi and Mosallanejad (2010) investigated the types of learning objectives represented in Iranian senior high school and pre-university English textbooks using Bloom's taxonomy of learning objectives. Three high-school textbooks and the sole pre-university textbook were included in the analysis. To codify the learning objectives, a coding scheme was developed based on Bloom's (1956) taxonomy of learning objectives. The results of the study indicate that in all grades lower-order cognitive skills were more prevalent than higher-order ones. Furthermore, the difference between the senior high school and the pre-university textbooks in terms of the levels of the taxonomy were significant insofar as the pre-university textbook used some degrees of higher-order learning objectives.

Bahrami (2011) attempted to conduct an in-depth evaluation of intermediate Top Notch based on Littlejohn's (1998) evaluative framework. The results showed some beneficial points for English teachers in many language institutes regarding the strengths and weaknesses of these intermediate textbooks which might give them some insights into the course book they use and how they can exploit it better.

As far as the review of literature in textbook evaluation in Iran is concerned, only a few studies have recently been conducted on the textbook evaluation. Besides, no study has been done on "Top-notch" series, which has recently come into the realm of L2 instruction.

\section{METHOD}

\section{A. Materials}

The sole source of materials in the present study is the two textbooks of Top Notch Fundamentals. Generally, Top Notch series consist of 12 textbooks on the whole, written by Joan Saslow and Allen Ascher, and published in the United States of America by Pearson Longman Incorporation in 2006. The focus of the present study is on the beginner levels of Top Notch series consisting of the two textbooks of Top Notch Fundamentals A and B, and containing 14 units on the whole, and each unit includes 3 conversations related to the particular topic of that unit.

\section{B. Data Collection Procedure}

According to Guerin (2004, p. 6), To have an appropriate sample size in Conversation Analysis, we need to analyze samples of 'natural' conversations based on the topics, or recall of such conversations if necessary, and find out how the topics are being used in those conversations: are they jokes; are they serious discussions of issues in which the speakers try to persuade each other; are they to entertain the group listening; are they gossiping devices? To do this, we must find ways to obtain far more social context (or topic) for any conversation or text than has been done before.

Based on this explanation about the sampling of conversation analysis, the criterion for sampling must be based on different topical contexts or themes. Therefore, since these two textbooks include 42 conversations in 14 topics, the present study has randomly selected 14 conversations from the two fundamental books, i.e. one conversation from each unit, which includes a specific topic or "social context." Each conversation in these books consists of a number of sentences ranging from 4 to 15 sentences, and each sentence contains 7 words on the average.

Another reason to choose this number of conversation sampling is that, in qualitative research, it is actually advised to use $10 \%$ of the whole population. Therefore, to be on the safe side, this study has covered $35 \%$ of the whole conversations in these fundamental textbooks. So, any issue related to sampling can be resolved (Committee Members of Shiraz University, 2010).

\section{Data Analysis Procedure}

As the study is mainly qualitative, no special statistical analyses have been needed. Therefore, the entire analysis of the present study has been carried out by careful inspection of the conversations included in the two books of Top Notch Fundamentals on the basis of Searle's (1976) speech acts and Halliday's (1978) language functions models. The 
purpose of this observation was to find out the types of speech acts and language functions involved in the contents of the conversations. Basically, the only quantitative analysis performed in this study includes some simple statistical analyses like counting the frequencies of the occurrence of each sub-category of Searle's (1976) speech act taxonomy and Halliday's (1978) language function model as well as their percentages presented in different tables and shown on several figures. Moreover, the chi-square test was reported in order to better illustrate the distribution levels of these pragmatic variables.

\section{Results}

Tables 4.1 to 4.4 clearly depict this general view regarding the distribution of these pragmatic factors, i.e. the frequencies and percentages of language functions and speech act, respectively:

TABLE 4.1

OVERALL FREQUENCIES AND PERCENTAGES OF LANGUAGE FUNCTIONS

\begin{tabular}{|l|l|l|l|}
\hline Code & Functions & Frequency & Percentage (\%) \\
\hline $\mathbf{1}$ & Instrumental & 8 & 7.47 \\
\hline $\mathbf{2}$ & Regulatory & 5 & 4.67 \\
\hline $\mathbf{3}$ & Interactional & 17 & 15.88 \\
\hline $\mathbf{4}$ & Personal & 12 & 11.21 \\
\hline $\mathbf{5}$ & Heuristic & 18 & 16.82 \\
\hline $\mathbf{6}$ & Imaginative & 0 & 0 \\
\hline $\mathbf{7}$ & Informative & 34 & 31.77 \\
\hline $\mathbf{8}$ & Attention-getting & 13 & 12.14 \\
\hline $\mathbf{T}$ & Total & 107 & 100 \\
\hline
\end{tabular}

Based on Table 4.1, the percentages of language functions show that $7.47 \%$ refers to instrumental, $4.67 \%$ regulatory, $15.88 \%$ interactional, $11.21 \%$ personal, $16.82 \%$ heuristic, $0 \%$ imaginative, $31.77 \%$ informative, and $12.14 \%$ attentiongetting functions. Therefore, looking at this table, one can conclude that the overall minimum of all language functions deals with imaginative ones, i.e. $0 \%$, while the overall maximum of all refers to informative functions, i.e. $31.77 \%$. Moreover, Table 4.3 shows the results of the chi-square test regarding these language functions:

TABLE 4.3

CHI-SQUARE RESULTS

\begin{tabular}{|l|l|}
\hline & Frequency \\
\hline Chi-Square & $35.028^{\mathrm{a}}$ \\
$\mathrm{df}$ & 6 \\
Asymp. Sig. & .000 \\
\hline
\end{tabular}

a. 0 cells $(.0 \%)$ have expected frequencies less than 5. The minimum expected cell frequency is 15.3.

According to this table, the difference between the frequencies of these language functions is significant and meaningful. In other words, the language functions in the conversations of Top Notch Fundamentals are not distributed equally and not at the same or close levels of frequency, i.e. Sig. $=.000(\mathrm{p}<.05)$.

Furthermore, Table 4.4, as previously mentioned, presents the overall frequencies and percentages of speech acts used in the sample conversations of both books A and B:

TABLE 4.4

OVERALL FREQUENCIES AND PERCENTAGES OF SPEECH ACTS

\begin{tabular}{|l|l|l|l|}
\hline Code & Speech Acts & Frequency & Percentage (\%) \\
\hline $\mathbf{1}$ & Representative & 31 & 31 \\
\hline $\mathbf{2}$ & Commissive & 7 & 7 \\
\hline $\mathbf{3}$ & Directive & 27 & 27 \\
\hline $\mathbf{4}$ & Expressive & 35 & 35 \\
\hline $\mathbf{5}$ & Declarative & 0 & 0 \\
\hline $\mathbf{T}$ & Total & 100 & 100 \\
\hline
\end{tabular}

As Table 4.4 shows, both the frequency and percentage of representative speech acts are 31 , those of commissive ones equals 7 , directive ones 27 , expressive ones 35, and those of declarative speech acts are 0 . As a result, it can simply be concluded that the overall minimum frequency and percentage belong to declarative speech acts, i.e. 0 , and the overall maximum ones refer to expressive speech acts, i.e. 35. Moreover, Table 4.6 shows the result of the chisquare test regarding these speech acts: 


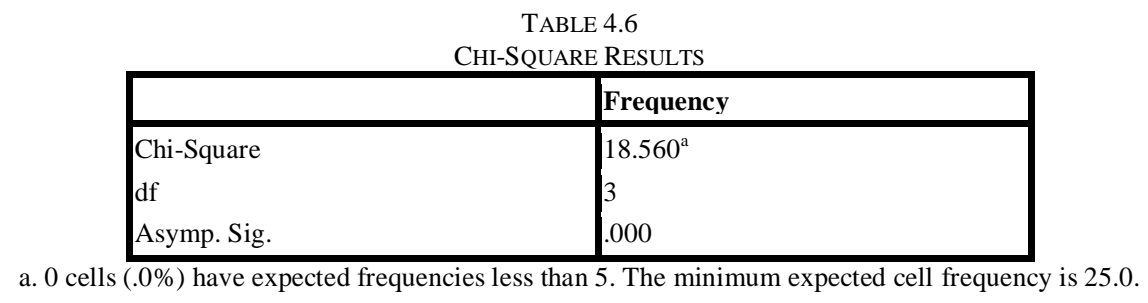

Based on this table, the difference between the frequencies of these speech acts is significant and meaningful. In other words, the speech acts in the conversations of Top Notch Fundamentals are not distributed equally and not at the same or close levels of frequency, i.e. Sig. $=.000(\mathrm{p}<.05)$.

\section{Discussion}

Research Question 1: What are the types of language functions in the conversations texts?

As it was revealed in the results section, out of the eight language functions in Halliday's (1978) model, one function, i.e. imaginative function, was absent among other functions in both Top Notch Fundamentals A and B. In other words, seven types of Halliday's (1978) language functions, including instrumental, regulatory, interactional, personal, heuristic, informative, and attention-getting functions, were present in the sample conversations of both textbooks (Table 4.1). As a result, the lack of the imaginative function in all of the conversations of these two textbooks may be regarded as a pitfall for those who are trying to improve their speaking skill through these textbooks.

According to Halliday (1978), the imaginative function is one of the crucial and effective functions in the real-life communication which is applied to create a world of one's own or extend one's own environment for humorous esthetic purposes such as telling jokes. This lack of such a communicative function is strongly in opposition to the claim of Top Notch producers, who are for sure in favor of CLT approach and claim that the conversations in Top Notch are communicatively and functionally powerful. The significance of the imaginative function is revealed in the moments of thinking, assuming, remembering, telling jokes, problem-solving, doing puzzles, playing tongue twisters, inventing, painting, doing artistic things, and many other activities one does in everyday life. With regard to what Cutting (2002) states, a good conversation takes all the felicity conditions or the real contexts and roles of participants into account. Therefore, it can be concluded that one of these conditions or contexts in real-life situations deals with those contexts in which the imaginative function is used. Top Notch Fundamentals lack these contexts in their conversation sections.

Research Question 2: How frequently each language function is used?

In Pragmatics, to know the frequency of language functions is so crucial that it may change the viewpoints towards textbooks and put them under the limelight of total judgment and overall evaluation. As Corwin (1989) mentions, a unique feature of pragmatics is its thorough analysis of the loci and frequency of communication variables (Hamre, 1984). One of the main focuses of the present study is to know the frequency of these pragmatic variables, i.e. language functions, in the sample conversations of Top Notch Fundamentals. In fact, it is the frequency of these language functions that reveals the main part of the answer to the most important research question of the current study, i.e. Research Question 5, which will be discussed later.

As Table 4.1 illustrated in the result section, there is no imaginative function in the sample conversations of these two fundamental textbooks. Therefore, the frequency and the percentage for this function is zero, which is a significant shortcoming of these books. As it was stated in the previous research question, other types of Halliday's language functions were observed in these conversations with variable frequencies. Regarding the percentages of language functions, $7.47 \%$ refers to instrumental, $4.67 \%$ regulatory, $15.88 \%$ interactional, $11.21 \%$ personal, $16.82 \%$ heuristic, $31.77 \%$ informative, and $12.14 \%$ attention-getting functions. Looking at these frequencies and percentages of these language functions, one can recognize the fluctuations among these pragmatic variables in these conversations. According to Halliday (1978), and also based on what Cutting (2002) says, a good conversation consists of all of the language functions with an equal distribution throughout the textbook. In other words, real conversations in real-life situation contain all of the Halliday's (1978) language functions. Although in many cases of real communications and authentic conversations there exist restricted types of language functions and perhaps there would be no need to apply all their types, a good textbook must include conversations containing all types of these language functions distributed equally throughout the conversations of the book so as to make learners pragmatically competent in their speaking performance. For instance, if a learner starts learning English and is exposed to a textbook with a number of conversations in it, is it logical or reasonable for the textbook to have all types of language functions in its conversations or limited types of them? As a result, it is better for a textbook, in general, or for the conversations in Top Notch Fundamentals, in particular, to include all types of these language functions so that it better activates this functional network in the mind.

Furthermore, based on Halliday (1978), and as the result of the chi-square test shows in Table 4.7, the degree of distribution is another important point which has been ignored, to some extent, in these conversations, i.e. there is a significant difference in the distribution of the pragmatic variables in the conversations. Halliday (1978) states that although the frequencies of these language functions are variable and varied in real communication, the presence of all 
their types cannot be denied. Therefore, this very presence of all types of language functions in real communication persuades the material designers to include all of them at the same level of frequency in different contexts of use. In this respect, the conversations in Top Notch Fundamentals have two important shortcomings regarding the pragmatic variables of language functions: first, regarding the presence of all types of language functions, the conversations lack the imaginative function. Second, regarding the equal distribution of these functions, the language functions have been distributed unequally and at variant levels of frequency.

These shortcomings regarding the language functions in the conversations of these two textbooks will surely lead the learners to encounter with a number of difficulties in terms of their speaking performance in real communication. Therefore, learners tend to focus on some specific or limited types of language functions while learning through these books, so that they will become strong in the use of some types of the language functions, while they are weak in that of the others. So, in this pragmatic vein, Top Notch Fundamentals are considered as weak textbooks, and they need some reconsideration in this regard.

Research Question 3: What are the types of speech acts in the conversations texts?

According to Table 4.8, all types of speech acts, except for declarative speech act, exist in the sample conversations of Top Notch Fundamentals. In other words, the representative, commissive, directive, and expressive speech acts were observed in this sample. However, the absence of the declarative speech act in these conversations can be regarded as an important weakness in these two textbooks. As Cutting (2002) explains, declarative speech acts are used frequently in everyday communication. They are words and expressions that change the world by their very utterance, such as "I bet," "I declare," "I resign," "I announce," "I pronounce," and many other utterances which are used in different contexts. Therefore, the lack of the declarative speech act will surely mars the learners' speaking competence in those pragmatic contexts in which this critical speech act is needed to be applied. In his book of "Language and Power," Fairclough (1989) states:

Speech acts are a central part of pragmatics, which is in turn concerned with the meanings that participants in a discourse give to elements of a text... discourse type dictates the conventions for speech acts, and the conventions reflect the participants' ideology and social relationships (Cited in Cutting, 2002).

With regard to the above extract it can be concluded that the different types of discourse shape the contexts in which a number of appropriate speech acts must be used so as to form some specific social relationships. In line with Fairclough's (1989) idea, Searle (1976) also emphasizes that since the learners tend to become communicatively competent in almost all contexts so that they would be able to establish their ideologies and social relationships, the existence of all the felicity conditions in which all types of speech acts can be applied is necessary. As a result, the conversations in Top Notch Fundamentals lack this characteristic which Searle (1976) explains, i.e. to include all types of speech acts. Besides this shortcoming, the distribution level of the present speech acts, i.e. representative, commissive, directive, and expressive speech acts, in these sample conversations is the other side of the coin which will be assessed and discussed in the next research question.

Research Question 4: How frequently each speech act is used?

As Table 4.4 shows, both the frequency and the percentage of speech acts are the same. In other words, there are $31 \%$ representative, $7 \%$ commissive, $27 \%$ directive, 35\% expressive, and $0 \%$ declarative speech acts in the sample conversations of Top Notch Fundamentals. This result indicates that the frequency and the percentage of occurrence of speech acts in these conversations are totally different and unequal. On the one hand, as mentioned in the previous section, there is no declarative speech act observed in the sample conversations, and on the other hand, the distribution of other present speech acts, i.e. representative, commissive, directive, and expressive speech acts, in these conversations are so variant and unequal. The maximum percentage of speech acts belongs to expressive ones, i.e. $31 \%$, while the minimum percentage refers to declarative ones, i.e. $0 \%$.

Searle (1976) believes that all types of speech acts are frequently used in every day communication, and states that different kinds of situations or contexts lead us to use different types of speech acts in order to maintain the basic relationships in our social lives. As a result, to become pragmatically competent and functional in almost all the contexts of communication, learners need to gain the knowledge of all types of speech acts so as to be able to apply pragmatically appropriate speech acts in different communicative contexts. In this respect, the conversations of Top Notch Fundamentals do not contain all types of Searle's (1976) speech acts, on the one hand, and according to the results of the chi-square test in Table 4.10, the existing speech acts are not equally distributed throughout these conversations, on the other hand.

Research Question 5: Are the conversations of these two Top Notch Fundamentals pragmatically competent with regard to the existence and the distribution of speech acts and language functions?

According to the points discussed in the previous research questions with regard to the types and the frequency of language functions and speech acts in the conversations, it is revealed that the conversations in Top Notch Fundamentals have a number of significant shortcomings, such as the lack of imaginative language function, lack of declarative speech act, and above all, the inequality and variation in the distribution of both language functions and speech acts. To be regarded as pragmatically competent, the conversations in these two textbooks must include all types of language functions and speech acts which are all used in the real-life communications. Besides, these language functions and speech acts must be used and distributed among the conversations in such a systematic way that when 
being read, studied, and practiced, all types of them can be recognized in learners' speaking performance. In other words, not only must all types of these Halliday's (1978) language functions and Searle's (1976) speech acts be present in the conversations of the books, but also they must be distributed equally and at the same frequency or percentage among all of the conversations.

Furthermore, with regard to what Guerin (2004) states in terms of the type of sampling and the criterion for this sample to be analyzed, this equality in the distribution of language functions and speech acts must be on the basis of topical or thematic contexts. These contexts in these textbooks are, actually, in the same line with different units or chapters of the books, each of which deals with a particular and real-life topic or theme. Therefore, these pragmatic variables, i.e. language functions and speech acts, must be distributed equally not only all over the entire conversations of these two books, but also in each one of the units, which focuses on a particular and natural theme in everyday life.

Therefore, according to what has been said up to this point, the beginner-level textbooks of Top Notch series, i.e. Top Notch Fundamentals, have significant problems with regard to the pragmatic dimension. In other words, the results of the present study revealed that the conversations in Top Notch Fundamentals are not pragmatically competent and learners are strongly recommended to be more careful of these two beginner-level textbooks if they choose them to start improving their speaking performance through their conversations. In fact, taking a quick look at the Figures 4.1 and 4.2 in the results section, one can easily recognize the above-mentioned pitfalls.

\section{CONCLUSION}

According to the research problem stated in the first chapter, assessing textbooks that appear efficacious on the surface and are used frequently here and there just on the basis of a vague perception of the people about them becomes necessary for those who are making these choices. Top Notch series, particularly Top Notch Fundamentals which are the focus of the present study, are also in the same vein. In other words, since Top Notch series are new or newlyarrived textbooks, they have become so popular in the context of Iran and those who choose to start learning English through Top Notch Fundamentals mention just one main reason for their choice, and that is its novelty. Therefore, this study was so curious to know about the pragmatic nature of these series and started its work from analyzing the conversations of their beginner-level textbooks, i.e. Top Notch Fundamentals, so as to illustrate how the conversation sections of these two textbooks provide the learners with adequate communicatively and pragmatically competent information.

\section{PEDAGOGiCAL IMPLiCATIONS OF THE STUdY}

Based on the results and the conclusions of the study, the following pedagogical implications can be stated with the hope that the present study would be a useful source to solve many problems in the area of language learning and teaching, material production, textbook design, discourse analysis, conversation analysis, and even test construction:

1. First of all, this study can mainly be beneficial for teachers since they will have an idea about the degree of the pragmatic strength in the conversation sections of Top Notch Fundamentals, so that they can better compensate for the shortcomings.

2. This study can also provide material developers and textbook writers with the necessary information regarding the pragmatic dimension of the conversation sections of these beginner-level textbooks.

3. Textbook developers can take the pragmatic pitfalls of the conversations of Top Notch Fundamentals into consideration as a useful source to modify and revise other developing textbooks.

4. This study recommends the developers and the editors of Top Notch Fundamentals to take the reported pragmatic shortcomings under the rigorous scrutiny so as to consider and use all types of language functions and speech acts, and to balance them to the same range or level.

5. In line with Tavakoli's (1995) research, the present study also suggests the explicit teaching of language functions and speech acts as a sort of remedy to these pragmatic pitfalls in textbooks since the semantic-syntactic structure of utterances does not usually reveal their real functions especially in the case of indirect ones.

\section{SUGGESTIONS FOR FURTHER RESEARCH}

Regarding the present research, a number of areas in which interested researchers can conduct further related studies are presented in this part:

1. Further research in the similar vein is needed to be done on the other textbooks of Top Notch series and Summits.

2. Top Notch series can be examined from different aspects other than the pragmatic one.

3. The same investigation can be conducted in terms of the other sections of these book rather than the conversation sections.

4. This study can be replicated and conducted on different textbooks other than Top Notch series.

5. Further research is also needed regarding classroom observation and detailed teacher interviews so as to determine how Top Notch Fundamentals or other Top Notch textbooks are incorporated into the students' learning process.

\section{REFERENCES}


[1] Amerian, M. (1987). A Comparative Study of The Graded English and The Right Path to English Series with regard to Content and Methodology. Unpublished master's Thesis. Shiraz University.

[2] Austin, G. (1962). How to do things with words. Oxford: Oxford University Press. In Thomas, J. (1995). Meaning In Interaction: An Introduction to Pragmatics. Longman: London and New York.

[3] Berry, R. (2000). You-ser friendly metalanguage: What effect does it have on learners of English? International Review of Applied Linguistics in Language Teaching, 38, 195-211.

[4] Brown, D. (2007). Principles of Language Learning and Teaching. New York: Longman Pearson.

[5] Darali, Gh. (2007). Pragmatic Dimension in Spectrum Textbooks. Unpublished master's thesis. Shiraz University.

[6] Fraser, B. (1983). The Domain of Pragmatics. En J.C. Richards YR. W. Schmidt, Language and Communication. Londers: Longman.

[7] Halliday, M. A. K. (1985). Spoken and written Language. Victoria: Deakin University Press.

[8] Halliday, M. (1975). Learning how to Mean. London: Edward Arnold.

[9] Leech, G. N. (1983). Principles of Pragmatics. London: Longman.

[10] Matreyek, W. (1990). Communicating In English Examples Models, And Functions. London: Prentice Hall International.

[11] McDonough, J. and Shaw, C. (1993). Materials and Methods in ELT. Blackwell Publishers Inc. Oxford: Oxford University.

[12] Mosallanejad, N. (2008). A Textbook Evaluation on the Basis of Searle's Speech Act Taxonomy. Unpublished master's thesis. Shiraz University.

[13] Nunan, D. (1989). Introducing Discourse Analysis. Asian EFL Journal, 5(4), 23-40.

[14] Otlowski, M. (2003). Ethnic diversity and Gender bias in EFL textbooks. Lecture, Kochi University, Japan.

[15] Rastegar, Z. (1992). The Analysis of Dialogue in Iranian Guidance and High School Texts in Terms of their pragmatic Functions. Unpublished master's thesis. Shiraz University.

[16] Razmjoo, S. A. and Soozandehfar, S. M. A. (2010). The Effects of Anxiety and Gender on Learners' Speaking Performance. Sino-US English Teaching, 7 (6), 1-12.

[17] Riazi, A.M. (2003). What do Textbook Evaluation Schemes Tell Us? A Study of The Textbook Evaluation Schemes of Three Decades. In W. Renandya (Ed). Methodology \& Materials Design in Language Teaching. pp. 52-68. Singapore SEMEO Regional Center.

[18] Richards, J. C. and Schmidt, R. (2002). Longman Dictionary of Language Teaching and Applied Linguistics. London: Pearson Education.

[19] Searle, J. (ed.). (1971). The Philosophy of Language. Oxford: Oxford University Press.

[20] Searle, J.R. (1965). What is a speech act? In Max Black (ed.), Philosophy in America. Ithaca: Cornell University Press.

[21] Searle, J.R. (1969). Speech acts. Cambridge: Cambridge University Press.

[22] Sheldon, L.E. (1988). Evaluating ELT textbooks and materials. English Language Teaching Journal, 42(4), $237-246$.

[23] Stephen, D. (1984). Evaluating and Selecting EFL Teaching Materials: Cunningsworth, Heinemann Educational Books. International Journal of Educational Development, 6(1), 79-80.

[24] Swales, J. (1980). ESP: The textbook problem. The ESP Journal, 1(1), 11-23.

[25] Tanck, Sh. (2002). Speech Act sets of refusal and complaint: A comparison of native and non-native English speakers' production. American University, Washington, DC.

[26] Tavakoli, F. (1995). Functional Analysis of the Dialogues in the Iranian Senior High School English Textbooks. Unpublished master's thesis. Allame University, Tehran.

[27] Thibault, P.J., \& Leeuwen, T.V. (1996). Grammar, society, and the speech act: Renewing the Connections. Journal of Pragmatics, 25(4), 561-585. Retrieved 12/2007 from: www.sciencedirect.com.

[28] Thomas, J. (1983). Cross-cultural pragmatic failure. Applied Linguistics, 4, 91-112.

[29] Tomlinson, B. (2001). Materials development. In R. Carter \& D. Nunan (Eds.), The Cambridge Guide to Teaching English to Speakers of Other Languages. (pp: 66-71). Cambridge: Cambridge University Press.

[30] Toolabi, J. (2002). Characterization of Language Functions in the Iranian High School English Textbooks. Unpublished master's thesis. Shiraz University.

[31] Tsui, A.B.(1995). English conversation. Oxford: Oxford University Press.

[32] Tucker, C. A. (1975). Evaluating beginning textbooks. English Language Teaching Forum, 13 (3-4), 335-361.

[33] Vellenga, H. (2004). Learning Pragmatics from ESL \& EFL Textbooks: How Likely? TESL-EJ, 8 (2), 25-38.

[34] Williams, D. (1983). Developing criteria for textbook evaluation. ELT Journal, 37 (3), 251-255.

[35] Xu, I. H. (2004). Investigating criteria for assessing ESL textbooks. Retrieved March 3, 2009 from: http://proquest.umi.com.

[36] Yakhontova, T. (2001). Textbooks, contexts, and learners. English for Specific Purposes, 20, 397-15.

[37] Yule, G. (1996). Pragmatics. Oxford: Oxford University Press.

Seyyed Mohammad Ali Soozandehfar is a Ph.D. student in TEFL, Department of Foreign Languages and Linguistics at Shiraz University, Shiraz, Iran. He received his BA in English Language and Literature and his MA in TEFL from Shiraz University. He teaches and translates English at different institutes. He is also skillful in doing research in TEFL.

Rahman Sahragard is an assistant professor in Applied Linguistics, Department of Foreign Languages and Linguistics at Shiraz University, Shiraz, Iran. He teaches Sociolinguistics, Discourse Analysis, Pragmatics, Research Methods, and Materials Development at postgraduate level. 